\title{
Habit Beyond Psychology
}

The Evolution of The Concept

\section{Aleksandar Feodorov}

\section{(2) OpenEdition}

\section{Journals}

Electronic version

URL: http://journals.openedition.org/ejpap/1007

DOI: $10.4000 /$ ejpap. 1007

ISSN: 2036-4091

\section{Publisher}

Associazione Pragma

\section{Electronic reference}

Aleksandar Feodorov, « Habit Beyond Psychology », European Journal of Pragmatism and American Philosophy [Online], IX-1 | 2017, Online since 22 July 2017, connection on 12 June 2020. URL : http:// journals.openedition.org/ejpap/1007 ; DOI : https://doi.org/10.4000/ejpap.1007

This text was automatically generated on 12 June 2020 .

\section{(c) $(1) \&$}

Author retains copyright and grants the European Journal of Pragmatism and American Philosophy right of first publication with the work simultaneously licensed under a Creative Commons AttributionNonCommercial-NoDerivatives 4.0 International License. 


\title{
Habit Beyond Psychology
}

\author{
The Evolution of The Concept
}

\author{
Aleksandar Feodorov
}

\section{Introduction}

1 Psychologists would often attribute the success or failure of our everyday behavior to the habits we develop throughout our lives. Walking, eating or even speaking are acquired habits, whereas physiological processes like breathing or even the ability to think - inherent habits or instincts. Beyond the level of the individual, all conventions of society and moral values signaling the emergence of civilization can be analyzed into elements, which form a structural equivalent to the habits of a single person. Since it is possible to approach a given multitude such as a congestion of atoms or a social community as an individual, nothing surprising emerges out of these propositions: there is no immediate reason to doubt the effects of habit. However, this does not make an explanation of the phenomenon redundant. In the following text I reexamine the connotations of the term habit from the perspective of Peirce's pragmatism. I start by tracing back the roots of the term in the Metaphysical Club's discussions of Alexander Bain's theory of belief. By stressing the relative overlap between belief and habit I am also proposing that the latter term transcends the boundaries of empirical psychology. Peirce's well-known antipathy to psychologism in logic raised the status of habit to a universal concept that participates in the unlimited process of interpretation. Habit, therefore, falls into a new lineage of meaning that can be traced back to antiquity and turns into a generative notion with extensive connotations. As a result it becomes an inseparable part of Peirce architectonic philosophy, capable to shed new light on his evolutionary cosmology and metaphysics. Conceiving of habit as an operative element in the evolution of all phenomena in the universe is the main objective of this article. 


\section{Peirce's Anti-Psychologism}

2 Pragmatism was never a fully integrated philosophical theory and Arthur Lovejoy's article "The Thirteen Pragmatisms" published in 1908 is an apt illustration. In roughly a decade after William James introduced the term to a wider audience in his lecture "Philosophical Conceptions and Practical Results" (1898) the first genuine American contribution to philosophy sprouted into an abundance of directions. In the first years of the 20th century, pragmatism gained followers not only in the US but also in Europe. Notable 'niches' of the new doctrine emerged in the UK with the work of Francis Canning Scot Schiller (1864-1937), the Florentine School in Italy, represented by Giovanni Papini (1881-1956), Giuseppe Prezzolini (1882-1982), Giovanni Vailati (1863-1909) and Mario Calderoni (1879-1914), and even on the Balkans with the undeservedly forgotten Bulgarian philosopher Ivan Sarailiev (1887-1969). The works of the latter might have exercised a greater impact, if they were not written almost exclusively in Bulgarian and if they were not "heavily suppressed by the communists after they gained power in 1944" (Mladenov 2014: 46). In such a context of rapid development and not before many arguments with James, Peirce started using the term 'pragmaticism' to designate his method for deriving meaning, zealously trying to protect it from misinterpretations and abuse "in the merciless way that words have to expect when they fall into literary clutches" (CP 5.414). The reason for the invention of the new name is debatable, but his motives are discernible from his harsh criticism of the pragmatists following James's vision for a theory of truth and their implicit disregard for the normative character of logic. Peirce envisioned pragmatism as a logical, or rather semeiotic, method for discerning the meaning of intellectual conceptions (e.g. symbols and arguments). For that reason he refused to accept that it could be reduced to the 'will to believe' and the consequent grounding of logic in psychology.

3 As Christopher Hookway aptly stresses in his The Pragmatic Maxim, from his earliest publications in the 1860s to his unpublished manuscripts from the early years of the 20th century Peirce insisted that "information from psychology and other natural sciences had no relevance to research in logic" (Hookway 2012: 83). For Peirce psychology is a discipline studying how we think, thus belonging to the domain of

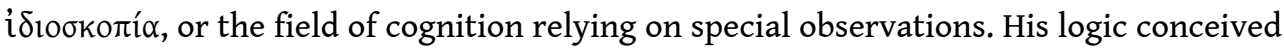
as semeiotic, on the other hand, was concerned with how we should or ought to think thus falling within the domain of kolvoбкотí $\alpha$, or the field of cognition based on the shared experience of humanity. This anti-psychologism as regards logic and the other normative sciences of esthetics and ethics represents a stable tendency throughout Peirce's oeuvre. In his Harvard lectures of 1865 Peirce argues that the failings of psychologistic approaches to logic have been consistently shown by philosophers of the Kantian stripe and that "we ought to adopt a thoroughly unpsychological view of logic" (W 1: 164). In his "Lessons in Practical Logic" he declares that "all questions of psychology are [...] irrelevant to the science of logic" (W 2:349). He further stresses that "all the psychology in the world will leave the logical question just where it was" (EP 2: 217), denies that "the phenomena that psychologists discover have any bearing upon the theory of reasoning" (EP 2: 385) and asserts that all attempts to ground logic in psychology are "essentially shallow" (CP 5.28). These are only a few of Peirce's attacks on the different attempts to ground logic on psychology. What is the reason for Peirce's 
insistence to employ a non-psychological notion of logic? Hookway gives the following answer:

Peirce claims that if we are to make external criticisms of our current ways of thinking, we have to recognize possible thoughts, ones that currently have no psychological role in our beliefs and reasoning. We understand such thoughts by identifying their logical properties. Hence normative criticism of thought and inference requires an objective or logical conception of thought. (Hookway 2012: 101; original emphasis)

4 In Peirce's own terminology these so called 'possible thoughts' are named would-be's. Peirce explains that "no agglomeration of actual happenings can ever completely fill up the meaning of a "would-be"' (EP 2: 402) and adds that "no collection whatever of single acts, though it were ever so many grades greater than a simple endless series, can constitute a would-be, nor can the knowledge of single acts, whatever their multitude, tell us for sure of a would-be" (CP 2.667).

But there are two remarks to be made; first, that in the case under consideration a person is supposed to be in a condition to assert what surely would be the behavior of the subject throughout the endless series of occasions - a knowledge which cannot have been derived from reasoning from its behavior on the single occasions; and second, that that which in our case renders it true, as stated, that the person supposed "ipso facto knows a would-be of that subject," is not the occurrence of the single acts, but the fact that the person supposed "was in condition to assert what would surely be the behavior of the subject throughout an endless series of occasions. (CP 2.667; original emphasis)

Peirce explained in depth his logical anti-psychologism in his projected but unfinished The Minute Logic (see CP 2.18-78) and Hookway was among various commentators to further explicate Peirce's aversion to grounding logic on psychology. For that reason it seems more productive to follow a different line of thought in approaching a wider meaning of habit that goes beyond the level of empirical psychology. More accurately, I will focus on the evolutionary use of the term, which represents another feature of Peirce's criticism of the customary meaning of psychologism from a metaphysical perspective. Paradoxically a good starting point would be a pshychologistic treatment of the concept.

It is difficult to establish whether Peirce wanted to completely disregard the nominalistic, or rather psychologistic, branches of pragmatism by inventing a new name for his method focusing not only on actual but on all conceivable thoughts (the would-be's in question) or simply to stress his own version as belonging to a philosophical movement quite heterogeneous in its origin but still devoted to the overcoming of the mind-body split of Cartesianism. Nonetheless, it is a fact that 'pragmaticism' looks for its application not on simple terms and propositions, but on complex intellectual concepts and arguments, which function as beliefs or habits of thought. For Peirce belief is only an instance of the general concept of habit. The meaning of those terms was central to the newly emerging pragmatic movement since its birth in the 1870s in the Metaphysical Club formed in Cambridge, in which the ideas of the Scottish associationist philosopher Alexander Bain (1818-1903) were discussed in depth. 


\section{What Does the Metaphysical Club Believe In?}

7 The influence of one of the founding fathers of modern day psychology Alexander Bain on pragmatist thought has often been underestimated. However, his idea of belief as that upon which a person is prepared to act was widely discussed among the members of the Metaphysical Club. Influenced by philosophers such as Thomas Reid (1710-96), Sir William Hamilton (1788-1856) and his close friend John Stuart Mill (1806-73), Bain developed positions that led him to the idea that questions regarding feeling, sensation and perception cannot be an object of study for metaphysicians. He was convinced that the inner workings of the human mind should be approached solely with the methods of empirical psychology. In his treatise The Emotions and the Will (1859) Bain argues that belief has meaning only in relation to action and adds that the essence of belief is the "expectation of some contingent future about to follow on our action" (Bain 1859: 568-9). According to Peirce, this idea was introduced in the Metaphysical Club by the lawyer Nicholas St. John Green (1830-76), although Louis Menand argues that the true source was James Fitzjames Stephen's (1829-94) book A General View of the Criminal Law in England (1863) (Menand 2001: 225). Stephen, like Bain, argued that all action presupposes a belief and that successful conduct is based on true beliefs. It is a short step from here to the conclusion that without beliefs one would not be able to initiate action, whereas without true beliefs successful conduct would be impossible.

[...] the ultimate reason for believing is, that without belief men cannot act. And the reason for believing what is true is, that without true belief they cannot act successfully; thus the advantage derived from true as distinguished from false belief, and not the bare fact that the thing is true, is the reason for believing what is true [...] If all the affairs of life, moral and intellectual education included, could be conducted as well by a person who believed that twice two make six, as by one who believed that twice two make four, there would be no reason for believing the one proposition rather than the other. Hence, belief is not mere impression which the mind receives passively from contemplation of facts external to it, but an active habit involving an exertion of will. (Stephen 1863: 242)

Disagreements over the true inspiration for the introduction of belief into the discussions of the Club still exist, but Peirce maintained that Bain was one of the precursors of pragmatic thought. Even if Green was not familiar with Bain's works, the same cannot be said about James who taught psychology at Harvard based on his theories, or about other members of the Club such as Oliver Wendell Holmes Jr. (1841-1935), Chauncey Wright (1830-75) and Peirce who all cited Bain. Their analyses of Bain's works might be defined as an attempt of the early pragmatists to go beyond the Cartesian heritage of modernity. Opposing Descartes's maxim of universal doubt and his epistemological skepticism, the members of the Club were seeking a way out of the mind-body dualism by arguing that all action is based on belief from which it follows like in a logical syllogism a consequent arises from a premise. Thus, pragmatism from its birth disregards universal doubt as a meaningless principle. The reason is that the sceptic cannot initiate goal-directed and controlled action before at least some of her initial beliefs which were doubted are restored. It is in this respect that Bain's psychological philosophy has been a major influence for the pragmatic movement.

9 An interesting fact is the negligence of the Metaphysical Club's members, Peirce being the only exception, to acknowledge in a written text or a public statement Bain's influence on the birth of pragmatism. On the other hand, Bain himself never 
commented on the works of Peirce, James and the other Cambridge intellectuals. In the beginning of the new century Peirce commented on the progress of the new philosophy and diligently recorded all scholars worth mentioning. As for the relation between belief and habit, it seems that Bain was the most deserving and Peirce seems to reach the same conclusion when he writes that pragmatism is a natural consequence from the definition of belief as "that upon which a man is prepared to act" (CP 5.12). Max H. Fisch argues that it was only in 1907 when Peirce made the connection between his method and Bain (Fisch 1954: 413). Confirming the validity of Peirce's 'story' of the birth of pragmatism should, however, be examined in relation to other facts such as the relative 'silence' in regard to Bain by other early pragmatists and Bain's own lack of comment on the development of pragmatism. Moreover, the only earlier mention of Bain and pragmatism in a single sentence discovered by Fisch was by the British Hegelian Francis Bradley (1846-1924) in his article "On Truth and Practice," in which he has taken a rather critical stance towards Schiller's version of pragmatism.

It would [...] be interesting to know how our new gospel [i.e. pragmatism] conceives its relation to Dr. Bain's theory of belief. It might seem to have taken that theory, and, without considering the objections to which it is liable, to have gone beyond it by simply writing "truth" for "belief." (Bradley 1904: 314-5)

10 In order to fully appreciate the intended meaning of the concept habit a careful study of Bain's influence over the early development of pragmatism is needed. A possible approach would be to follow closely the structure of Fisch's article "Alexander Bain and the Genealogy of Pragmatism." In this way I will elaborate on the content of Bain's theory of belief, examine its influence on the Metaphysical Club's members and indicate what Peirce 'borrowed' from Bain.

\section{Bain's Pragmatism}

11 The most provoking as well as the most controversial part of Bain's works - The Senses and the Intellect (1855) and The Emotions and the Will later combined into The Mental Sciences (1868) - is the proposed theory of belief. His ideas mark a decisive divergence from those of James Mill (1773-1836) and John Stuart Mill, who conceived belief respectively as an inseparable association of ideas, which once established in the mind cannot be removed thereupon, and as a sort of 'deposited' meaning, brought about by a multitude of connections among various concepts, which the mind has compiled. Bain, on the other hand, considered belief as a disposition to act. His main goal was to describe more fully the process of association of ideas in the mind, while at the same time transforming the associationists' doctrines in such a way as to found their bases in physiology and to postulate the existence of an innate activity of mind. According to Bain, anyone who thinks of belief as an inseparable association of ideas is making a serious mistake.

The prevailing error on this subject consists in regarding Belief as mainly a fact of the Intellect, with a certain participation of the feelings. The usual assumption is, that if a thing is conceived in a sufficiently vivid manner, or if two things are strongly associated in the mind, the state of belief is thereby induced. (Bain in Mill 1869: 394) ${ }^{1}$

Nobody can deny that feelings and intellectual vigor play a part in belief, yet they do not capture its essence. Belief is first and foremost growth and development of the active nature of the human mind, i.e. an effect of the will. The tendency of living 
organisms to act is manifested in a variety of instances depending on certain conditions, which assume the form of beliefs, desires or intentions. If an action is spontaneously initiated, it will find its spontaneous effect in case it eliminates an external irritation or if it brings pleasure to the individual. Notwithstanding, Fisch argues that it "is when actions indifferent in themselves are carried through in anticipation of a subsequent fruition, that the will exhibits the complication called belief" (Fisch 1954: 419). For Bain a belief is measured according to two principles: motor and emotional. Based on this dichotomy, he infers that the highest degree of belief is achieved when the individual mind manages to pursue mediate goals with the same energy invested in achieving final goals and that mind is as satisfied at achieving them as if a final goal were reached. For that reason, belief would be an empty word if it is not studied in relation to action. It is of great importance to understand that here Bain follows the classical Aristotelian division between potentiality and actuality corresponding to two distinct mental states.

Every one recognizes the old distinction of potentiality and actuality (posse and esse) as a true account of two states of mind that we practically assume. Besides actually doing a thing, we know what it is to be in an attitude or disposition of preparedness to act, before the emergency has arisen, or while the emergency is still at a distance and uncertain. (Bain 1859: 595)

Even if certain situations or events never happen, the belief would stay intact as a readiness to act in case the opportunity for its realization arises. In her life every person develops many beliefs, which adapt her to the environment. This is obviously true for a person belonging to a civilized society, in which personal development is always intimately connected with some sort of institutional indoctrination. However, the probability of actualizing a great many of the acquired beliefs remains little. Fisch emphasizes that the readiness to act is always potentially present and that this "readiness constitutes the belief" (Fisch 1954: 420). Yet, by comparing belief with habit, it should be added that Bain does not include the same meaning which is called upon by the ancient Greek term ह̌ $\xi \varsigma$ or the scholastic habitus, which will be examined on the following pages. However, for a strong adept of ancient and medieval scholastic philosophy such as Peirce those terms better represent the potential readiness to act than a mere psychological investigation of habits.

The feeling of believing is a more or less sure indication of there being established in our nature some habit which will determine our actions [...] Belief does not make us act at once, but puts us into such a condition that we shall behave in a certain way, when the occasion arises. (CP 5.371-3)

Bain is closest to pragmatism and to Peirce in particular when he opposes belief to doubt. The lack of a belief is not a mental state opposite to the state of having a belief, but simply a belief in something else. The true opposite is a state of doubt and uncertainty. Whereas belief ensures subjective certainty in the accomplishment of a particular goal and leads to a gratifying state of mind, doubt causes a state of inconvenience and uneasiness in the individual. Based on such notions Bain draws the conclusion that every person aims at upholding a state of belief, overcoming in such a way the effects of anxiety caused by doubting. Experience and emotion might participate in the formation of mental habits in this respect, but the true source of belief is mainly the characteristic "primitive credulity" of the human intellect (Bain 1859: 582). Accumulated experience does not beget beliefs, but rather it corrects them and makes them general. To generate a new belief the individual has to experience a 
surprise, which would in turn create a feeling of uncertainty and doubt. Only after this uncomfortable experience is superseded can we speak of the establishment of a new belief.

We are all faith at the outset; we become sceptics by experience, that is, by encountering checks and exceptions. We begin with unbounded credulity, and are gradually educated into a more limited reliance. (Bain 1868: 382)

Bain thinks of belief as a predisposition to follow a certain pattern in actions with a formal structure that reflects something already experienced in the anticipation of achieving similar results. It follows that belief always contains an intellectual element, i.e. it is always reasonable to an extent and presupposes some regulatory principle. This seems to imply that the external universe is rational and that it serves as a basis for controlled action. In case one encounters an unexpected obstacle, the continuity of action is breached. As a result, a break in the conceptual scheme formed by the individual occurs, accompanied by a state of surprise and disappointment from the inadequate expectation. This state negates the preceding belief, which could only be reinstated in a modified version to reflect the novelty brought by experience. These remarks serve to close the discussion on the content of Bain's theory and to turn to the presence of that theory in the works of the early pragmatists.

Apart from James, who used Bain's treatises in his academic lectures in psychology and philosophy, Oliver Wendell Holmes Jr. and Chauncey Wright were two other important members of the Metaphysical Club, who adopted much of the theory of belief in their own works. It is an interesting fact, one that has not been studied enough, that the Club was composed almost exclusively of lawyers. One of them was Holmes, who would later become Supreme Judge and a leading theoretician of law with his doctrine of 'legal pragmatism.' By the early 1870s Holmes had already developed an intricate prognostic theory of law, which had much in common with Bain's conception of belief. The theory was based on the idea of the transformation of customs into laws by accepting new rules and regulations on the part of the court. According to him, before such a transformative process is fulfilled, a custom functions only as a motive for taking a particular juridical decision. In such a case the most basic theoretical problem of law is whether an individual legal decision would influence the outcome of future cases of a similar type. In societies governed by the rule of law, the will of the sovereign (the people) is the source of the law. However, those who exercise it - the judges - form the 'body' of the law.

The only question for the lawyer is, how will the judges act? Any motive for their action, be it constitution, statute, custom, or precedent, which can be relied upon as likely in the generality of cases to prevail, is worthy of consideration as one of the sources of law, in a treatise on jurisprudence. Singular motives, like the blandishments of the emperor's wife, are not a ground of prediction, and are therefore not considered. (Holmes Jr. 1872: 724)

These ideas play a prominent part in the intellectual development of Holmes and they are more elaborately developed in his lecture "The Path of the Law" (1897), in which the object of study for all legal scholarship is defined as the "prediction of the incidence of the public force through the instrumentality of the courts" and law itself as a body of "dogma or systematized prediction" (Holmes Jr. 1897: 61-2). Unlike Holmes, Wright sought in Bain's theory of belief a direct link to the Darwinian theory of evolution and the principles of individual mental development. 

conclusions over the problems of consciousness and mind. According to him, cognition and belief are results of a process of selection, in which only the fittest of them would have a chance to 'survive' and 'reproduce.' Among the primal characteristics of mind Wright points to the ability to reproduce the past through the powers of remembering and believing.

Among these native faculties of the individual mind is the power of reproducing its own past experiences in memory and belief; and this is, at least, analogous [...] to the reproductive powers of physical organisms, and like these is in itself an unlimited, expansive power of repetition. Human beliefs, like human desires, are naturally illimitable. The generalizing instinct is native to the mind. It is not the result of habitual experiences, as is commonly supposed, but acts as well on single experiences, which are capable of producing, when unchecked, the most unbounded beliefs and expectations of the future. (Wright 1877: 115)

Wright there is a clear analogy between mental processes and the processes of the physical universe. The formation of habits is then considered as a logical process and the formal structure of the struggle for survival in the natural world is comparable to that of a logical inference. For Wright many conceive of belief and habit as mere phases of the development of the individual mind, but Bain's greatest achievement and contribution is in reaching the true essence of belief. This is the tendency to act while trying to accomplish a determined final goal. Such a goal acts as a norm of conduct: as a horizon which we aim towards following the logical matrix of habit. Thus, habit is not a singular action and cannot be exhausted by the sum of similar actions; it is rather a rule of action, almost a necessity, which, however, also includes all potentialities of the will that might never be actualized: Peirce's would-be.

In contrast to Holmes and Wright, Peirce maintained a more critical stance towards some hypotheses proposed by Bain. Peirce studied closely the works of Bain and the utilitarians Jeremy Bentham (1748-1832) and Mill, only to reject the inherent nominalism in their theories. For him belief has meaning not simply in relation to particular action but rather in relation to general concepts. A fundamental principle in his architectonic philosophy is the idea that the world exists in order to be cognized and that mind and matter are continuous. To the idea that mind and matter differ not in essence, but only in degree, and that they are continuous without a sharp boundary between the two, Peirce gave the name synechism.

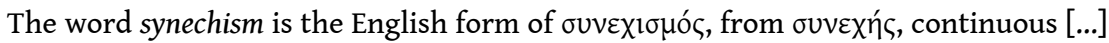

I have proposed to make synechism mean the tendency to regard everything as

continuous [...] I carry the doctrine so far as to maintain that continuity governs the

whole domain of experience in every element of it. (EP 2:1)

The doctrine of continuity is a direct consequence of Peirce's evolutionism and his corresponding metaphysical theory of objective idealism, which argues that the one intelligible theory of the universe is "that matter is effete mind, inveterate habits becoming physical laws" (CP 6.24-5). On such a basis Peirce proposed the thesis that logical conclusions and thinking per se are composed of generalizations, attained by observations of individual occurrences. Building on that, Peirce argues for the acceptance of a level of reality, which encompasses the universe of abstractions. In the beginning of the 20th century Peirce was considering the reality of three logical universes or modalities: the objects belonging to each he names "Ideas" or "Possibles" (referring to Firstness, spontaneity, potentiality), "Things" or "Existents" (referring to Secondness, determination, actuality) and "Necessitants" (referring to Thirdness,

European Journal of Pragmatism and American Philosophy, IX-1 | 2017 
habit-taking, continuity) (EP 2: 479). The mistake of nominalism and the psychologization of the term habit is thus the attempt to limit it to the 'universe' of Secondness, actuality, the 'mechanical' sum of singular actions.

Peirce's philosophy has undergone numerous transformations, but one aspect remained unchanged: that was the desire to go beyond nominalism, which latently dictated the development of thought in the 19th century. We can observe such a mental thrust in the development of his pragmatism and the normative character, ascribed by him to logic, ethics and aesthetics. If ratiocination is a form of acting, then it is not only a subject of logic, but also of ethics. Peirce approaches the problem of what a norm is as an aspect of a relation between phenomena of the real world to goals such as Truth (logic), Good (ethics) and Beauty (aesthetics). Thus, from a method for deriving the meaning of a certain concept, manifested in the sum total of its conceivable practical bearings, Peirce's pragmatism evolved into a doctrine for establishing the content of intellectual concepts and their application towards particular goals.

Pragmaticism was originally enounced in the form of a maxim, as follows: Consider what effects that might conceivably have practical bearings you conceive the objects of your conception to have. Then, your conception of those effects is the whole of your conception of the object.

I will restate this in other words, since ofttimes one can thus eliminate some unsuspected source of perplexity to the reader. This time it shall be in the indicative mood, as follows: The entire intellectual purport of any symbol consists in the total of all general modes of rational conduct which, conditionally upon all the possible different circumstances and desires, would ensue upon the acceptance of the symbol (CP 5.438).

This evolution of the original method unfolded over a period of several decades, in which Peirce made numerous discoveries in various fields of research. Without a doubt one of the most important ideas which he would put to the torch of pragmatism was that of habit and its relation to evolutionary and mental processes.

\section{The Law of Habit}

The idea of habit as an effect of the transformation of thought into action developed during the 19th century with the first steps of empirical psychology, which strove to build a theoretical framework refuting the mind-body dualism of modernity. How would modern day psychologists define habit?

[...] a well-learned behavior or automatic sequence of behaviors that is relatively situation specific and over time has become motorically reflexive and independent of motivational or cognitive influence - that is, it is performed with little or no conscious intent. (APA Dictionary of Psychology, 2015)

It follows that habits have an evolutionary function at the level of the individual consciousness. They adapt the behavior of a person in accordance with the dynamics of her environment and help maintain a state of equilibrium in her mental states. Habits, thus, are engaged in the economy of thought via automatizing behavior, which always follows certain general patterns or models, while preserving enough flexibility within the concreteness of the context and the specificity of the individual instance.

Peirce might accept such definition of habit and its evolutionary-adaptive function for the individual as long as it applies specifically to empirical psychology. However, for him habit is an element of every observable phenomenon in the universe. In this case 
the question is whether the principle of habit-formation is operative in processes such as the expanding of the universe, the evolution of biological organisms and the cultural and historical development of humanity. If it is possible to apply habit to all these phenomena, then it would mean that a purely psychical (not psychological) principle is operative at all levels of reality. Thus, we would have to deny all forms of determinism and absolutism because in the realm of mental phenomena there is an element of spontaneity. It is thanks to spontaneity that novelty emerges, variety is born, old habits are modified and new ones come into being. Moreover, any process contains the possibility of mistake, or rather deviation from the norm. For the better part of the 19th century scientific thought considered the laws of mechanics as absolute thus suppressing the role of spontaneity. However, those laws can hardly account for the heterogeneity of observable phenomena and the processes which give birth to novelty and growth. Applied in the field of the mental and the cultural they expose their own insufficiency by using absurd forms of reductionism.

Pragmatism, on the other hand, approaches necessity and determination only as effects of an ongoing, continuous, unlimited and incomplete process of growth. If the idea of predetermination has any meaning in terms of evolutionism it is through the hypothesis that in every object there is a tendency to develop from a primal state of pure spontaneity into a final state of complete determination (from Firstness to Secondness via Thirdness). Here I refer to Peirce and his understanding of matter and mind as continuous. In this framework the law of habit is really operative in the universe, successfully bridging the gap between body and mind.

I believe the law of habit to be purely psychical. But then I suppose matter is merely mind deadened by the development of habit. While every physical process can be reversed without violation of the law of mechanics, the law of habit forbids such reversal. Accordingly, time may have been evolved by the action of habit. (W 8: 387)

According to the law everything in the universe acquires habits and as a consequence becomes determined. Peirce built on this principle his general law of mind, proposed in "The Law of Mind" (1892). In this text he argues that exact logical analysis of mental phenomena shows that ideas have a tendency to grow continuously and thus affect other ideas. In this process they "lose intensity [...] but gain generality and become welded with other ideas" (EP 1: 313). Before continuing the current discussion, I offer a detour presenting aspects of the development of habit in the history of philosophical thought. This serves as an illustration of how meaning grows as well as an explanation of the workings of habit.

\section{Habit Develops}

According to Peirce, any "philosophical doctrine that should be completely new could hardly fail to prove completely false" (CP 5.11). Pragmatism is indeed an original contribution to the history of philosophy, but key aspects of the doctrine are traceable to antiquity. Peirce himself jokes that pragmatists of all stripes and schools have simply assimilated the methods of experimental science, which are nothing more than the old logical rule of the gospels: "By their fruits ye shall know them" (EP 2: 401, and Matthew 7: 20). The same rule holds true in reference to the concept of habit, which is central to pragmatism and especially to Peirce's pragmaticism, regardless of whether we are dealing with logic, semeiotic, phaneroscopy or metaphysics. 

was among the first philosophers to produce a systematic study of habit by adopting the term $\varepsilon$ ह̌ $\iota_{\zeta}$ from Plato's dialogue Theaetetus. Transformed into the Latin habitus the concept was used with similar meanings by Thomas Aquinas (1225-74) and Duns Scotus (1265-1308) among others. In the tradition of British empiricism and among the associationists like David Hume (1711-76), John Stuart Mill and Alexander Bain the term was transformed into the English habit. More accurately, ع̌ $\xi \varsigma$ and habitus have also been translated as 'state,' 'possession' and 'disposition,' but habit seems to offer the greatest heuristic potential as well as the highest degree of generality.

Plato's Theaetetus is a fundamental text in the history of epistemology. Peirce called it one of the greatest works of ancient thought together with Parmenides and the dialogue was an inspiration for many thinkers among which Ludwig Wittgenstein (1889-1954), who referred to Theaetetus in his Philosophical Investigations (1953). The central question of the dialogue is "What is knowledge?" which is discussed in a dialogue between Socrates and the young Theaetetus. After refuting all of the answers proposed by Theaetetus, Socrates himself is careful not to give a definite answer to the question he raised. Instead, the problem is metaphorically approached: Socrates argues that knowledge is in fact having or possessing knowledge (Plato 1921: 205 [197, b]). Plato uses the word $\dot{\varepsilon} \xi ı$, from which Aristotle would derive his $\check{\varepsilon} \xi ı$. According to Plato's Socrates there is a difference between possessing knowledge and having acquired the power of using that knowledge. He uses two examples to illustrate his thesis to Theaetetus.

Socrates: Well, then, having does not seem to me the same as possessing. For instance, if a man bought a cloak and had it under his control, but did not wear it, we should certainly say, not that he had it, but that he possessed it [...] Now see whether it is possible in the same way for one who possesses knowledge not to have it, as, for instance, if a man should catch wild birds - pigeons or the like - and should arrange an aviary at home and keep them in it, we might in a way assert that he always has them because he possesses them, might we not [...] And yet in another way that he has none of them, but that he has acquired power over them, since he has brought them under his control in his own enclosure, to take them and hold them whenever he likes, by catching whichever bird he pleases, and to let them go again; and he can do this as often as he sees fit. (Plato 1921: $207[197, b]$ )

Plato conceives knowledge not as a passive state of mind, but as an activity: having acquired knowledge, one is actively knowing. Possessing knowledge then means its controlled and willful exercise. Moreover, knowing is a present potentiality to be applied (the actualization of potentiality), when the knower decides or is forced by necessity.

Knowing is either having in hand knowledge that one has acquired and making real use [...] of it, or having the actual power of taking hold of this knowledge because one already has it under the hand, exactly as the owner of the doves in the dovecote has the determinate possibility to take hold of them. In other words [...] knowledge would be either an act, or a power focused in a specific sense; that is to say, an actual aptitude, which Aristotle will later categorise as second potentiality and, equally, as first actuality [...] for example, that of an educated man who is sleeping, but who completely retains his ability, on waking, to exercise his knowledge in a very specific domain and in a very specific sense. (Rodrigo 2011: 10-1)

This example points to the relative overlap between Plato's and Aristotle's usage of habit. However, Aristotle's ह̌ $\xi_{1 \zeta}$ attracts more meanings in its orbit, which vary according to the context. In his ethical writings he defines virtues as habits, which split into moral and intellectual. In Physics habits expand even further to include physical

European Journal of Pragmatism and American Philosophy, IX-1 | 2017 
states, caused by changes in the bodily features of a person. In On the Soul Aristotle defines knowledge as a result of qualitative change, reached through repetitive transition from one state to another. As Fuchs writes, the actualization of knowledge "represents the development of an existent quality from potentiality towards fixity (habit) or nature" (Fuchs 1952: XIV). This development is possible thanks to the presence of general concepts in the intellect in relation to the sensory channels. In Metaphysics Aristotle examines habits as properties or predispositions, via which a given object manifests its inner tendencies or its ability to enter into a relation with something else. In Categories habit is considered under the banner of 'quality.'

$$
\begin{aligned}
& \text { By "quality" I mean that in virtue of which men are called such and such. The word } \\
& \text { "quality" has many senses. Let habits and dispositions here constitute one kind of } \\
& \text { quality. The former are unlike the latter in being more lasting and stable. } \\
& \text { Comprised among what we call "habits" are virtues and all kinds of knowledge. For } \\
& \text { knowledge is considered as lasting and hard to displace from the mind, though a } \\
& \text { man may, in fact, have acquired it in only a moderate measure, unless some great } \\
& \text { change should come over him, thanks to disease or the like. And the same will hold } \\
& \text { good of the virtues - for instance, of temperance, justice. For these are allowed on } \\
& \text { all hands to be hard to dislodge or displace. (Aristotle 1962: 63-5 [Cat. 8: 8b]) }
\end{aligned}
$$

Aristotle also discusses the nature of habits when he examines the category "relation." According to him habits, states, sensory impressions and even knowledge are always relative, i.e. they are such only in relation to something else. Thus, habits are always habits for something and knowledge - knowing something. Aristotle's habit is dynamical, always directed to the accomplishment of goals and ideals. They in turn are determined and unchanging, being external to the mind and directing the formation of the correct habits, i.e. they function as norms, final and frozen instants which all movement tries to reach. When we argue that something is 'good' we have to say that this is an instance of the 'entelechy,' the principle that guides the transformation of potentiality into actuality. Habit not only allows one action to be repeated but also, as Rodrigo remarks, "in actively focusing it, it leads it to be exercised better, and it also leads it to realize the fulfilment of its object according to a typical determination" (Rodrigo 2014: 14). Aristotle's conception of habit then is of a universal principle or better - a phenomenon of generality. A single act is not equivalent to a habit, but only an actualized instant, which belongs to a class or type. The reason is that the actionrules of a habit encompass all conceivable states (i.e. potential as well as actual). Habit, however, remains as a guiding matrix, which activates and translates into action, directed at a certain goal in accordance to some norm.

Thomas Aquinas and Duns Scotus were among the scholastic philosophers to revive Aristotle's treatment of habit through the concept of habitus. For Aquinas habits contain potentiality that is directed at actions (Aquinas 1915: 9-14 [Sum. Th. I-II, q. 49, a. 3 and q. 50, a. 2]). Habits are a necessary element of the natural order and Aquinas explains their effects by examining the laws according to which potentialities transform into actualities. In order to explain knowledge as a result of habit-formation

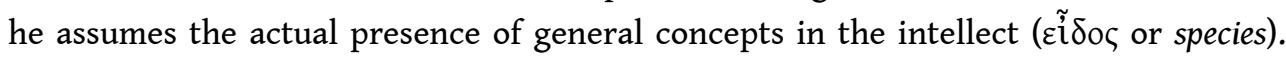
They in turn are cognizable and understandable likenesses of the objects of reality. Ideas have the same form like things in the material world and are reached through abstraction of the fancies, i.e. the concrete, individual mental representations. Forming the substance of the intellect, ideas are directed to the operations of conversion and remembering. Aquinas considers them as habits as long as they participate in the predisposition of the individual mind to reproduce knowledge, acquired through the 
will. According to him the nature of habit is intimately connected with the will: in other words, all habits are teleological and each is a result of controlled effort.

Every power which may be variously directed to act, needs a habit whereby it is well disposed to its act. Now since the will is a rational power, it may be variously directed to act. And therefore in the will we must admit the presence of a habit whereby it is well disposed to its act. Moreover, from the very nature of habit, it is clear that it is principally related to the will; inasmuch as habit "is that which one uses when one wills." (Aquinas 1915: 23-4 [Sum. Th. I-II, q. 50, a. 5])

Habits make possible the cognition of reality by preserving themselves in time through the active power of the will. Fuchs thinks that this interpretation is valid in light of Aquinas's idea of the will as "the real subject of virtues viewed as moral habits" (Fuchs 1952: XVI).

According to Duns Scotus, habit is a definite predisposition, which is available in the intellect. He considers some ideas to be characteristics of habits because they enable mental operations and are more or less lasting qualities, but they are not habits per se. Habit is the ability to reproduce passed actions and events through repetition. For him, like for Aquinas, moral virtues are habits, which are 'present' in the will, before the will actualizes into concrete actions. Thus, habit exists continuously as a potential that preserves and causes a pattern of behavior, enacted by the will. Physical skills are also considered as manifestations of habit through the continuous repetition of particular actions, which aim to accomplish an ideal norm.

The philosopher whose name most naturally attaches to the idea of habit in modernity is doubtlessly David Hume. In his Enquiry Concerning Human Understanding he argues that habit and custom - two terms that he considers synonymous (Hume 1900: 43) - are principles of fundamental importance in human nature. It is only thanks to habit that we are able to trace and infer logically causal relations between the events we observe, instead of perceiving them as sequences guided by chance.

Custom, then, is the great guide of human life. It is that principle alone which renders our experience useful to us, and makes us expect, for the future, a similar train of events with those which have appeared in the past. Without the influence of custom, we should be entirely ignorant of every matter of fact beyond what is immediately present to the memory and senses. We should never know how to adjust means to ends, or to employ our natural powers in the production of any effect. There would be an end at once of all action, as well as of the chief part of speculation. (Hume 1900: 45)

Although this limited presentation of the idea of habit from Plato, Aristotle, Aquinas, Duns Scotus and Hume does not cover the rich history of the concept in its entirety, it does reveal, above all else, a core of meanings with a potential far exceeding the boundaries of empirical psychology. By defining habit as a psychical principle, Peirce follows a heritage, which gives birth to meanings quite different from Bain's narrow understanding of habit as belief. Let us see what habit can do beyond psychological concerns. This entails to dwell into Peirce's evolutionism and metaphysics in order to suggest further possibilities for the development of the concept.

\section{Habit beyond Psychology}

Belief as an instance of habit was among the concepts discussed between the members of the Metaphysical Club. However, for Peirce habit is a concept that transcends the 
boundaries of human consciousness. According to him, every phenomenon in the universe develops from a state of chaos and indeterminacy to a state of increasing determination guided by a habit-taking tendency (or once again from Firstness to Secondness via Thirdness). The most general formulation of evolution given by Peirce is "growth in the widest sense of that word" (CP 1.174). By growth it is not meant the mechanical and quantitative increase of biological species or cultural artefacts, for example, but an increase of the complexity of relations between different elements in a system and the differentiation of the communicative channels between bordering systems. In Peirce's pragmatism a general concept is subordinate to the principles of evolutionary growth and its meaning is in a process of continuous development of the relations between its elements and the environment in which they exist. How can we explain the ever growing variety in the universe? The only possibility is to allow for spontaneity, which under the influence of habit becomes determinate. For Peirce the most obvious characteristic of the universe is its heterogeneity, which leads him to the conclusion that it cannot be a result only of the blind forces of the laws of mechanics, because this:

[...] is a philosophy which leaves no room for a God! No, indeed! It leaves even human consciousness, which cannot well be denied to exist, as a perfectly idle and functionless flâneur in the world, with no possible influence upon anything - not even upon itself. (CP 1.162)

41 According to Peirce's evolutionary cosmology, the universe emerged from a pure state of vagueness (First) and slowly develops to a state of pure determination (Second), and the mediating process is characterized by an increase of complexity, or rather by a habit-taking tendency (Third). The inherent tendency of the objects of reality to acquire habits is seen as the dynamical element of a triadic relation in which spontaneity and necessity enter. In every manifestation of the universe we can observe processes of renewal and of repetition, where the transformation of the first into the second follows a logical succession similar to that of establishing beliefs. Thus, in both cases we describe the effects of habit. The continuous movement of the universe and its relative stability in time are major problems approached in Peirce's metaphysics and

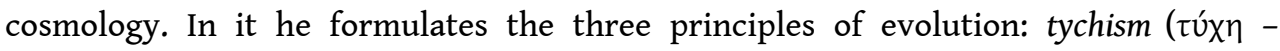

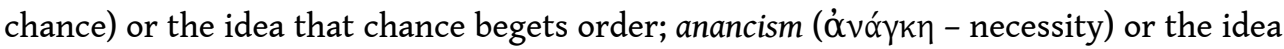
that phenomena are relatively determined; and agapism ( $\dot{\alpha} \gamma$ ó $\pi \eta$ - love) or the idea that evolution is teleological and all phenomena acquire habits through the power of love and compassion.

Three modes of evolution have thus been brought before us; evolution by fortuitous variation, evolution by mechanical necessity; and evolution by creative love. We may term them tychastic evolution, or tychasm, anancastic evolution, or anancasm, and agapastic evolution, or agapasm. The doctrines which represent these are severally of principle importance, we may term them tychasticism, anancasticism, and agapasticism. (EP 1: 362)

Peirce developed the idea of evolution as an interplay between chance variations, mechanical necessity and creative love (which roughly correspond to the evolutionary theories of Darwin, Wallace/Spencer and Lamarck respectively) in his essay "Evolutionary Love" (1893). He finds the results of tychastic evolution in the increase and endless variations of living organisms and cultural practices. However, the most important aspect of tychasm is the suggestions that chance and spontaneity beget order by the acquisition of habits. This means that an evolutionary stance should be assumed 
in regards to all phenomena in the world, including physical laws which grow and develop. The proposition that order comes out of spontaneity was diametrically opposed to the prevalent ideas of determinism in the 19th century, but it has been extremely influential to modern day chaos theories. A century after Peirce's death the Nobel Prize winner Ilya Prigogine (1917-2003) wrote that:

[...] Peirce's metaphysics was considered as one more example of a philosophy alienated from reality. But, in fact, today Peirce's work appears to be a pioneering step toward understanding of the pluralism involved in physical laws. (Prigogine \& Stengers 1984: 303)

Agapastic evolution is discernible not only in the domain of metaphysics, but also of physics: its effects can be observed in the evolution of social and mental phenomena. Moreover, agapasticism, which is an aspect of a philosophy of habit, can be instrumentalized into a method for social, political and institutional reforms that is mediating progressivism and conservativism. As an example we should only mention Peirce's essays "Why Do We Punish Criminals?" and "Dmesis" (1892), in which he developed a method of applied agapasm for the reeducation of criminals in order to prove the logical validity of the Christian doctrine that God is love. Moreover, to fully appreciate the role of habit beyond psychology a thorough investigation of Peirce's logic (semeiotic), his classification of signs and his triadic conception of the interpretant ought to be conducted.

\section{Is Habit Universally Valid?}

There is one question with regard to habit that persists. Namely, is the law of habit universal? We should not succumb to the temptation to consider the universal as synonymous to the absolute. The law of habit-taking is universal in the sense that it guides processes in the mental as well as in the material universe. However, it is not absolute because it allows innumerable deviations of the smallest degree, which in turn give rise to endless variation and unlimited evolution.

The hypothesis suggested [...] is that all laws are results of evolution; that underlying all other laws is the only tendency which can grow by its own virtue, the tendency of all things to take habits. Now since this same tendency is the one sole fundamental law of mind, it follows that the physical evolution works towards ends in the same way that mental action works towards ends, and thus in one aspect of the matter it would be perfectly true to say that final causation is alone primary. Yet, on the other hand, the law of habit is a simple formal law, a law of efficient causation; so that either way of regarding the matter is equally true, although the former is more fully intelligent. Meantime, if law is a result of evolution, which is a process lasting through all time, it follows that no law is absolute. That is, we must suppose that the phenomena themselves involve departures from law analogous to errors of observation. (CP 6.101)

If a person learns anything new urged by her own ignorance, i.e. by making mistakes, can we suggest that the universe - to the extent that it is itself mindfull and meaningladen - is in a perpetual process of learning itself? The action of habit can be seen as an actualization of the depositories of memory, the guiding principle for conserving knowledge through association, and yet flexible enough to allow dissociations and newly emerging associations. In the context of the universality of habit as overcoming the mind-body dualism of modern philosophy, the psychologism/anti-psychologism divide seems to be one more instance of that "obsolete Cartesian dualism" (CP 6.580) 
that renders mind and matter two distinct substances. The divide itself comes as a result of an attempt to approach the human mind as distinct from the physical universe in which it came to existence. Thus, the epistemological dilemma: do we look for the universal laws of logic 'outside' the human mind or, on the contrary, 'within' the limited scope of human consciousness? Peirce's evolutionary philosophy of synechism and objective idealism through the concept of habit offers a third way, the postmodern way to use the words of the late John Deely, which conceives of the human mind and the universe as continuous.

\section{BIBLIOGRAPHY}

APA DiCTIONARY OF PSYCHOlOgy, (2015), “Habit,” ed. Gary R. VandenBos, 2nd ed., Washington, DC, American Psychological Association, 479-80.

AQUINAS Thomas, (1915), The “Summa Theologica” by St. Thomas Aquinas, Part II (First Part), trans. Fathers of the English Dominican Province, London, R \& T Washbourne.

ARISTOTLE, (1962), The Categories. On Interpretation, trans. Harold P. Cooke \& Hugh Tredennick, Cambridge, MA, Harvard University Press.

BAIN Alexander, (1859), The Emotions and the Will, London, Parker and Son.

BAIN Alexander, (1868), The Senses and the Intellect, London, Longmans.

BRADLEY Francis H., (1904), “On Truth and Practice,” Mind, 13 (51), 309-35.

FISCH Max H., (1954), “Alexander Bain and the Genealogy of Pragmatism,” Journal of the History of Ideas, 15 (3), 413-44.

FUCHS Oswald, (1952), The Psychology of Habit According to William Ockham, St. Bonaventure, NY, Franciscan Institute.

HOLMES Jr. Oliver Wendell, (1872), “Book Notices,” The American Law Review 6, Boston, Little, Brown and Company.

HoLmES Jr. Oliver Wendell, (1897), “The Path of the Law,” Harvard Law Review, 10 (8), 457-78.

HOOKWAY Christopher, (2012), The Pragmatic Maxim. Essays on Peirce and Pragmatism, Oxford, Oxford University Press.

HUME David, (1900), An Enquiry Concerning Human Understanding, Chicago, Open Court.

JAMES William, (1907), Pragmatism, a New Name for Some Old Ways of Thinking. Popular Lectures on Philosophy, New York, Longmans, Green.

JAMES William, (1967), The Writings of William James. A Comprehensive Edition, ed. John J. McDermott, New York, Random House.

LOVEJOY Arthur O., (1908), “The Thirteen Pragmatisms,” The Journal of Philosophy, Psychology and

Scientific Methods, 5 (1), 8-12.

MENAND Louis, (2001), The Metaphysical Club, New York, Farrar, Straus, and Giroux. 
MILL James, (1869), Analysis of the Phenomena of the Human Mind, vol. 1, London, Longman, Green, Reader and Dyer.

MLADENOv Ivan, (2014), "The First Steps of Peirce in Bulgaria. From Ivan Sarailiev to Today,"

European Journal of Pragmatism and American Philosophy, 6 (1), 46-50.

PEIRCE Charles S., (1931-66), Collected Papers of Charles Sanders Peirce, vols. 1-6, eds. Charles

Hartshorne \& Paul Weiss, Cambridge, Massachusets, Harvard University Press, 1931-1935. Vols.

7-8, ed. Arthur W. Burks, Cambridge, Belknap of Harvard University Press, 1958. References are

given as CP followed by volume number and section number (For example CP 5.132).

PEIRCE Charles S., (1982-2010), Writings of Charles S. Peirce: A Chronological Edition, vols. 1-6 and 8 (of projected 30), eds. Max Harold Fisch, Christian J. W. Kloesel \& The Peirce Edition Project,

Bloomington, Indiana University Press. References are given as $\mathrm{W}$ followed by volume number and page number (For example W 3: 234).

PEIRCE Charles S., (1992, 1998), The Essential Peirce: Selected Philosophical Writings, vols. 1-2, eds. Nathan Houser \& Christian J. W. Kloesel, Bloomington and Indianapolis, Indiana University Press. References are given as EP followed by volume number and page number (For example EP 2: 208).

PLATO, (1921), Plato: Theaetetus, Sophist, trans. H. N. Fowler, London, Heinemann.

PRIGOGINE Ilya \& Isabelle STENGERS, (1984), Order out of Chaos: Man's New Dialogue with Nature, Toronto, New York, London, Sydney, Bantam Books.

RODRIGo Pierre, (2011), "The Dynamic of Hexis in Aristotle's Philosophy," Journal of the British Society for Phenomenology, 42 (1), 6-17.

STEPHEN James Fitzjames Sir, (1863), A General View of the Criminal Law in England, London and Cambridge, Macmillan.

WAAL Cornelis De, (2005), On Pragmatism, Belmont, California, Thomson Wadsworth.

WRIGHT Chauncey, (1877), Philosophical Discussions, New York, Henry Holt and Company.

\section{NOTES}

1. The quote is from James Mill's Analysis of the Phenomena of the Human Mind, which was published in 1869 with comments by Bain and John Stuart Mill.

\section{ABSTRACTS}

In the following text I reexamine the connotations of the term habit from the perspective of Peirce's pragmatism. I start by tracing back the roots of the term in the Metaphysical Club's discussions of Alexander Bain's theory of belief. By stressing the relative overlap between belief and habit I am also proposing that the latter term transcends the boundaries of empirical psychology. Peirce's well-known antipathy to psychologism in logic raised the status of habit to a universal concept that participates in the unlimited process of interpretation. Habit, therefore, falls into a new lineage of meaning that can be traced back to antiquity and turns into a generative notion 
with extensive connotations. As a result it becomes an inseparable part of Peirce architectonic philosophy, capable to shed new light on his evolutionary cosmology and metaphysics. Conceiving of habit as an operative element in the evolution of all phenomena in the universe is the main objective of this article.

\section{AUTHOR}

\section{ALEKSANDAR FEODOROV}

Bulgarian Academy of Sciences

a.n.feodorov[at]gmail.com 